\title{
Canadian connective tissue conference London, Ontario: an editorial
}

\author{
Andrew Leask ${ }^{1}$ \\ Received: 12 November 2015 / Accepted: 13 November 2015 /Published online: 18 November 2015 \\ (C) The International CCN Society 2015
}

This special issue of JCCS is devoted to a special meeting held in London, Ontario to honor the 20th anniversary of the first Canadian Connective Tissue Conference (CCTC). Guest of honor was Robin Poole, who helped organize the initial meeting. To mark this occasion, Robin was presented with a special award designed by David Holdsworth, co-director of the Bone and Joint Institute at the University of Western Ontario. For this issue, Robin has written an article describing the founding and evolution of the meeting and Canadian Connective Tissue Society from a historical perspective.

From its inception, the CCTC has focused on trainees, providing a forum for students and postdoctoral fellows to present their data. David O'Gorman and I were honored by being invited by Boris Hinz (of both the Canadian Connective Tissue and European Tissue Repair Societies) to organize the 20th CCTC in London Ontario. Like European-style meetings, the 20th CCTC was organized to break down barriers between faculty and trainees in order to maximize the educational experience. An example of such an event was the introductory mixer at Milos' Craft Beer Emporium. Such a style of meeting has parallels in similar meetings such as society meetings sponsored by the British Society of Matrix Biology, European Tissue Repair Society, our own International CCN Society as well as the Scleroderma Workshops. If the 20th CCTC was even able to approximate somewhat the style and success of these meetings, then we were successful.

Andrew Leask

Andrew.Leask@schulich.uwo.ca

1 Department of Dentistry, Department of Physiology and Pharmacology, University of Western Ontario, London, ON N6A $5 \mathrm{C} 1$, Canada 